\title{
РЕАЛІЗАЦІЯ ПРОКУРОРОМ ФУНКЦІЇ ОБВИНУВАЧЕННЯ ПІД ЧАС ОБҐРУНТУВАННЯ ПІДОЗРИ
}

Сухачова I. О.

Cтаття присвячена дослідженню реалізації прокурором функції обвинувачення під час обгрунтування підозри. Автором проведено аналіз наукових підходів до визначення «обгрунтована підозра», а також визначено підстави для здійснення повідомлення про niдозру ma їх види.

На підставі результатів аналізу практики Європейського суду з прав людини автор зазначає, що стандарт доказування «обгрунтована підозра», який застосовується прокурором у разі реалізації функції обвинувачення у досудовому розслідуванні злочинів характеризується такими критеріями: 1) обгрунтована підозра передбачає наявність фактів або інформації, які могли 6 переконати об'єктивного спостерігача у тому, що відповідна особа могла вчинити діяння, що підпадає під ознаки кримінального правопорушення, відповідальність за яке на момент його вчинення встановлювалася нормами КК; 2) обгрунтована підозра повинна грунтуватися на доказах, отриманих прокурором, достатніх у своїй сукупності для ухвалення відповідного рішення, і не може грунтуватися на припущеннях; 3) існування обгрунтованої підозри встановлюється національними судами і відображається у судових рішеннях шляхом наведення змісту підозри, обставин справи і доказів, які дозволяють обгрунтовано підозрювати особу у вчиненні кримінального правопорушення; 4) тягар доказування наявності обгрунтованої підозри покладається на прокурора та не може перекладатися на сторону захисту.

За результатами проведеного дослідження зроблено висновок, що повідомлення особі про підозру прокурором у разі реалізації ним функції обвинувачення - це результат розумової діяльності прокурора щодо оцінки наявних у матеріалах кримінального провадження доказів, які з достатньою переконливістю вказують на ймовірність вчинення кримінального правопорушення певною особою, що виражається у процесуальному документі, який складається в письмовій формі відповідно до норм кримінального процесуального закону України і вручається особі, яка підозрюється у вчиненні кримінального правопорушення, що зумовлює набуття цією особою процесуального статусу підозрюваного, а також створює передумови для подальшого руху кримінального провадження та виконання завдань кримінального судочинства.

Ключові слова: прокурор, функція обвинувачення, обгрунтована підозра, кримінальне процесуальне доказування.
Sukhachova I. O. Implementation by the prosecutor of the prosecution function during subjection of suspicion

The article is devoted to the study of the prosecutor's implementation of the function of accusation during the substantiation of suspicion. The author analyzes the scientific approaches to the definition of "reasonable suspicion", as well as identifies the grounds for notification of suspicion and their types.

Based on the results of the analysis of the case law of the European Court of Human Rights, the author concludes that the standard of proof "reasonable suspicion" used by the prosecutor in the prosecution in the pre-trial investigation of crimes is characterized by the following criteria: 1) reasonable suspicion to convince an objective observer that the person concerned could have committed an act that falls under the signs of a criminal offense, the responsibility for which at the time of its commission was established by the norms of the Criminal Code; 2) a reasonable suspicion must be based on evidence obtained by the prosecutor, sufficient in its entirety to make a decision, and may not be based on assumptions; 3) the existence of a reasonable suspicion is established by national courts and is reflected in court decisions by stating the content of the suspicion, the circumstances of the case and the evidence that allows a person to be reasonably suspected of committing a criminal offense; 4) the burden of proving the existence of a reasonable suspicion rests with the prosecutor and cannot be transferred to the defence.

According to the results of the study, it was concluded that the notification of the person of suspicion by the prosecutor in the implementation of the function of the prosecution - it is the result of the prosecutor's mental activity to assess the evidence available in the materials of criminal proceedings, which with sufficient conviction indicate the likelihood of a criminal offense by a person, expressed in a procedural document drawn up in writing in accordance with the Criminal Procedure Code of Ukraine, suspected of committing a criminal offense, which determines the acquisition of procedural status of the suspect by this person, as well as creates preconditions for the further movement of criminal proceedings and the implementation of the tasks of criminal proceedings.

Key words: prosecutor, prosecution function, reasonable suspicion, criminal procedural evidence.

(c) Сухачова І. О., 2020 
Постановка проблеми та іiї актуальність. Реалізація прокурором функції обвинувачення у доказуванні на досудовому розслідуванні полягає не лише у пошуку, виявленні, перевірці та оцінці доказів для встановлення фактичних обставин кримінального провадження в аспекті досягнення кінцевої мети доказування, а й у використанні доказів для прийняття кримінальних процесуальних рішень та здійснення процесуальних дій, зокрема повідомлення про підозру.

Проводячи аналіз функції обвинувачення у кримінальному процесі, можна говорити, що іiі зміст полягає у формуванні сукупності доказів для повідомлення особі про підозру у вчиненні кримінального правопорушення, формуванні сукупності доказів для складання обвинувального акта, підтриманні державного обвинувачення під час судового розгляду справи, поданні апеляційних і касаційних скарг. Отже, первинною формою реалізації функції обвинувачення $\epsilon$ повідомлення особі про підозру. Саме у пред'явленій підозрі формулюється первинне обвинувачення конкретної особи. Під час дослідження процесуального порядку повідомлення про підозру в аспекті реалізації прокурором функції обвинувачення у доказуванні на досудовому розслідуванні як у вчених, так і у практиків виникає низка питань, які належним чином не врегульовані на законодавчому рівні або $є$ дискусійними, що і зумовлює актуальність вибраної теми.

Аналіз останніх досліджень і публікацій. Дослідження окремих теоретичних та практичних питань функції обвинувачення, а також правова природа і процесуальний порядок повідомлення про підозру досліджувався значною кількістю вчених. Так, указані питання розглядалися у роботах Ю.П. Аленіна, А.О. Боруша, І.В. Гловюк, В.О. Гринюка, І.Г. Івасюка, О.В. Капліної, А.І. Палюха, Х.Р. Слюсарчук, В.І. Фаринника, М.Ю. Черкова, Л.В. Юрченко та інших. Безумовно, вказані вчені зробили значний внесок у дослідження інституту підозри у кримінальному провадженні. Незважаючи на це, реалізація прокурором функції обвинувачення під час обґрунтування підозри була досліджена неповною мірою та потребує більш ґрунтовного аналізу.

Метою статті $\epsilon$ вивчення особливостей реалізації прокурором функції обвинувачення під час обґрунтування підозри.

Виклад основного матеріалу. Вітчизняний законодавець у нормах кримінального процесуального закону широко оперує термінами «підозра» й «обґрунтована підозра», але не наво- дить визначення їх понять. У доктрині кримінального процесу наявні різноманітні підходи до розкриття змісту понять «підозра».

Так, Н.С. Карпов вказує, що повідомлення про підозру $\epsilon$ одним із найважливіших процесуальних рішень, яке приймається під час проведення досудового розслідування прокурором або слідчим за погодженням з прокурором [1, с. 134].

Водночас у доктрині кримінального процесу також не дається чіткого визначення поняття стандарту доказування «обґрунтована підозра». Зокрема, як зазначається у науковій літературі, обґрунтованою слід вважати підозру, яка ґрунтується на відомостях, що об'єктивно пов'язують підозрюваного із вчиненим кримінальним правопорушенням, при цьому така підозра не може ґрунтуватись лише на тому, що особа вчинила в минулому правопорушення, навіть аналогічне [2, с. 130]. Натомість, на підставі практики ЄСПЛ С.Ю. Бутенко зазначає, що «обґрунтована підозра» - це впевненість органів влади у тому, що особа скоїла правопорушення, передбачене кримінальним законодавством, яка виникла на підставі наявних фактів про це [3, с. 92]. Однак навряд чи можна погодитись з відповідним визначенням, оскільки будь-яка «підозра» як певне припущення, ймовірний висновок про існування певного факту не може передбачати та охоплювати собою «упевненість», оскільки «припущення» та «впевненість» - це дві протилежні за змістом та взаємовиключні категорії [4, с. 104].

Більш прийнятним видається визначення обґрунтованої підозри як добросовісного припущення про вчинення особою певного діяння, яке ґрунтується на об'єктивних відомостях, які можна перевірити у судовому розгляді та які спонукали б неупереджену та розумну людину вдатися до практичних дій, щоб з'ясувати, чи $\epsilon$ така підозра обґрунтованою [5, с. 116]. У відповідному визначенні поняття «обґрунтована підозра» важливим для усвідомлення суті відповідного стандарту доказування $\epsilon$ твердження про те, що припущення про вчинення особою певного діяння повинно ґрунтуватись на відомостях, які спонукали б вдатись до практичних дій для перевірки такого припущення. Відповідно до такого висновку «обґрунтована підозра» не $\epsilon$ інтуїтивним відчуттям, вона повинна передбачати можливість пояснення причини підозри [4, с. 104].

О.В. Фараон зазначає, що повідомлення про підозру - це один із важливих і відповідальних актів стадії досудового розслідування кримінального провадження, який має визначену процесуальну форму і зміст [6, с. 205]. 
На думку О.В. Капліної, повідомлення про підозру - це процесуальна діяльність, зміст якої полягає у складанні слідчим або прокурором письмового повідомлення про підозру та його врученні особі відповідно до ст.ст. 276-279 КПК України [7].

А.О. Боруш вважає, що акт повідомлення про підозру має велике політичне і юридичне значення. Він слугує одним із засобів забезпечення невідворотності відповідальності осіб, які скоїли небезпечні для суспільства діяння [8, с. 30].

В.О. Гринюк вказує, що підозра - це процесуальне рішення прокурора, слідчого (за погодженням із прокурором), яке ґрунтується на зібраних доказах під час досудового розслідування та в якому формується припущення про причетність конкретної особи до вчинення кримінального правопорушення з повідомленням про це такій особі та з роз'ясненням їі прав і обов'язків [9, с. 122].

Ю.П. Аленін та І.В. Гловюк зазначають, що аналіз положень КПК України та наукових джерел дає змогу виокремити такі значення категорії «повідомлення про підозру»: процесуальна діяльність, зміст якої полягає у складанні слідчим або прокурором письмового повідомлення про підозру та його врученні особі відповідно до ст. 276-279 кПК України 7].

Аналіз зазначених понять дозволяє зробити висновок про зв'язок виникнення підозри з діяльністю сторони обвинувачення, до якої законодавець відносить владних суб'єктів, які передбачені в п. 19 ч. 1 ст. 3 КПК України. 3 появою підозри починається реалізація прокурором функції обвинувачення, оскільки в наявності $€$ первинне обвинувачення.

Лише слідчий за погодженням з прокурором чи сам прокурор наділені виключними повноваженнями щодо повідомлення особі про підозру. Таким чином, підозра - це процесуальне рішення прокурора, слідчого за погодженням з прокурором, що ґрунтується на зібраних доказах під час досудового розслідування, у якому формується припущення щодо причетності конкретної особи до вчинення кримінального правопорушення з повідомленням про це такій особі та з роз'ясненням їі прав і обов'язків.

На підставі результатів аналізу практики Європейського суду з прав людини доходимо висновку, що стандарт доказування «обґрунтована підозра», який застосовується прокурором у разі реалізації функції обвинувачення у досудовому розслідуванні злочинів характеризується такими критеріями: 1) обґрунтована підозра передба- чає наявність фактів або інформації, які могли б переконати об'єктивного спостерігача у тому, що відповідна особа могла вчинити діяння, що підпадає під ознаки кримінального правопорушення, відповідальність за яке на момент його вчинення встановлювалася нормами КК; 2) обґрунтована підозра повинна ґрунтуватися на доказах, отриманих прокурором, достатніх у своїй сукупності для ухвалення відповідного рішення, і не може ґрунтуватися на припущеннях; 3) існування обґрунтованої підозри встановлюється національними судами і відображається у судових рішеннях шляхом наведення змісту підозри, обставин справи і доказів, які дозволяють обґрунтовано підозрювати особу у вчиненні кримінального правопорушення; 4) тягар доказування наявності обґрунтованої підозри покладається на прокурора та не може перекладатися на сторону захисту.

Термін «обґрунтована підозра» використовується вітчизняним законодавцем у КПК України для позначення необхідної умови: 1) ухвалення рішення про застосування заходів забезпечення кримінального провадження (п. 1 ч. 3 ст. 132); 2) вжиття уповноваженою службовою особою, що здійснила затримання, слідчим, слідчим суддею низки процесуальних дій, спрямованих на забезпечення прав затриманої особи (частини 2, 6 і 7 ст. 206, ч. 3 ст. 210 та ч. 1 ст. 213); 3) звернення прокурора до слідчого судді з клопотанням про дозвіл на проведення моніторингу банківських рахунків як негласної слідчої (розшукової) дії (ч. 1 ст. 269-1); 4) здійснення повідомлення про підозру (ч. 1 ст. 276) [10, с. 324].

Продовжуючи дослідження реалізації прокурором функції обвинувачення у разі доказування обставин, які обґрунтовують повідомлення особі про підозру, доцільно звернути увагу на підстави для здійснення такого виду процесуальної діяльності у кримінальному провадженні.

В.О. Гринюк вказує, що підстави повідомлення про підозру $\epsilon$ неоднорідними. Вчений також робить висновок про можливість їх поділу на дві групи: формальні та юридичні. До формальних підстав повідомлення про підозру віднесено такі, які передбачені п. а, п. б ч. 1 ст. 276 КПК України. Для них $є$ характерним не пряме, а побічне твердження про причетність особи до вчинення кримінального правопорушення. Формальні підстави для здійснення повідомлення про підозру $\epsilon$ вторинними, оскільки з'являються в результаті прийняття рішення про затримання особи чи застосування до неї запобіжного заходу. Юридичною підставою для здійснення повідомлення про 
підозру $є$ наявність достатніх доказів для підозри особи у вчиненні кримінального правопорушення. Зазначена юридична підстава для підозри є прямою, оскільки у слідчого, прокурора на досудовому розслідуванні зібрано достатню кількість доказів для підозри особи у вчиненні кримінального правопорушення. У зазначених посадових осіб склалося внутрішнє переконання, що саме ця конкретна особа підозрюється у вчиненні кримінального правопорушення [11, с. 94].

Слід зазначити, що, на відміну від ухвалення слідчим суддею, судом рішень про застосування заходів забезпечення кримінального провадження, а слідчим судом також і про проведення моніторингу банківських рахунків як негласної слідчої (розшукової) дії, використання стандарту доказування «обґрунтована підозра» нормами кримінального процесуального закону прямо не закріплене як необхідна умова здійснення повідомлення про підозру. Так, згідно з ч. 1 ст. 276 КПК України, повідомлення про підозру обов'язково здійснюється в порядку, передбаченому ст. 278 цього Кодексу, у випадках: 1) затримання особи на місці вчинення кримінального правопорушення чи безпосередньо після його вчинення; 2) обрання до особи одного з передбачених цим Кодексом запобіжних заходів; 3) наявності достатніх доказів для підозри особи у вчиненні кримінального правопорушення [12].

Аналізуючи наведені підстави повідомлення особи про підозру, О.В. Капліна обґрунтовано поділяє їх залежно від кількості доказів, які обґрунтовують підозру, на два види: 1) випадки, коли слідчому та/або прокурору вже достовірно відомо про факт вчинення кримінального правопорушення певною особою: зібрані достатні докази для підозри особи у вчиненні кримінального правопорушення та/або щодо особи необхідно обрати один із запобіжних заходів (пункти 2 і 3 ч. 1 ст. 276 КПК України); 2) випадки, коли доказів ще замало, знання слідчого чи прокурора на цьому етапі ще $є$ невизначеними, неповними, уривчастими, а висновок про вчинення кримінального правопорушення певною особою можна зробити лише на підставі того, що вона затримана на місці вчинення кримінального правопорушення чи безпосередньо після його вчинення (п. 1 ч. 1 ст. 276 КПК України) [7, с. 240]. Тобто як перший, так і другий з виокремлених видів підстав повідомлення про підозру передбачає наявність обґрунтованої підозри, рівень обґрунтованості якої водночас диференціюється залежно від підстав його здійснення. У зв'язку з цим обґрунтованою $є$ позиція І.В. Гловюк, О.А. Міцкан, М.А. Погорецького й А.С. Степаненка, які на основі системного тлумачення норм КПК України вказують на застосовність стандарту доказування «обґрунтована підозра» до здійснення повідомлення особи про підозру [13, с. 40; 14, с. 16].

Розглядаючи скарги на повідомлення про підозру, слідчі судді обґрунтовано вказують, що його перевірка з точки зору обґрунтованості підозри з урахуванням положень ст. 17 КПК України не входить до предмета судового розгляду, який здійснюється слідчим суддею відповідно до положень ч. 1 ст. 303 КПК України у стадії досудового розслідування, оскільки у цій стадії слідчий суддя не уповноважений вдаватись до оцінки отриманих слідством доказів та порядку їх отримання, давати оцінку зібраним доказам з точки зору їх допустимості, а без такої оцінки висновок щодо обґрунтованості повідомленої особі підозри $\epsilon$ неможливим. У стадії досудового розслідування слідчий суддя може оцінити лише достатність зібраних доказів для підозри певної особи у вчиненні кримінального правопорушення, не вдаючись до їх оцінки як допустимих [15; 16].

Таким чином, як свідчить проведений аналіз норм кримінального процесуального закону, стандарт доказування «обґрунтована підозра» являє собою нормативно закріплене правило, що відображає можливість ухвалення низки процесуальних рішень, передбачених нормами кримінального процесуального закону, лише за умови доведення прокурором обґрунтованості припущення про причетність особи до вчинення кримінального правопорушення на рівні, необхідному для постановлення відповідного процесуального рішення. Повідомлення особі про підозру у кримінальному провадженні здійснюється прокурором на підставі стандарту доказування «обґрунтована підозра», хоч законодавець прямо не зазначив про іiі необхідність для прийняття відповідного рішення прокурором у разі реалізації функції обвинувачення у досудовому кримінальному провадженні.

Рішення прокурора або слідчого за погодженням з прокурором щодо повідомлення певній особі про підозру у вчиненні кримінального правопорушення приймається не у вигляді постанови, а оформлюється спеціальним процесуальним документом у формі письмового повідомлення. Воно повинно відповідати вимогам, передбаченим ст. 277 КПК України. Таке повідомлення про підозру повинне містити відомості про особу, яка 
повідомляє про підозру, відомості про особу, якій повідомляється про підозру, відомості про кримінальне провадження, зміст підозри та правову кваліфікацію вчиненого, короткі відомості про обставини, а також зазначено права підозрюваного та підпис особи, яка повідомила про підозру $[17$, c. 23].

Дискусійним у теорії кримінального процесу завжди було питання про доцільність викладення у повідомленні про підозру доказів, на підставі яких прокурор прийняв рішення про притягнення особи до кримінальної відповідальності. Більшість учених вважають, що вимога вмотивованості рішення означає необхідність обов'язкового наведення в тексті документа доказів, що підтверджують висновки про наявність кримінального правопорушення і винуватості конкретної особи в його вчиненні [18, с. $190 ; 19$, с. 8]. Нам здається правильною вказана позиція, адже мотивування повідомлення про підозру звернене до сторони захисту, яка, знаючи про наявні докази, буде здатна подати клопотання про ознайомлення $з$ матеріалами у порядку ст. 221 КПК України і будувати захист із врахуванням цих доказів. Крім того, оцінку такій обґрунтованості повідомлення на стадії досудового розслідування даватиме сторона обвинувачення та прийматиме рішення про достатність зібраних доказів для висунення остаточного обвинувачення і можливості його якісного відстоювання перед судом. Тому повідомлення про підозру і повинне мати мотивування зовнішнього характеру.

Висновки. 3 огляду на викладене, доходимо висновку, що повідомлення особі про підозру прокурором у разі реалізації ним функції обвинувачення - це результат розумової діяльності прокурора щодо оцінки наявних у матеріалах кримінального провадження доказів, які з достатньою переконливістю вказують на ймовірність вчинення кримінального правопорушення певною особою, що виражається у процесуальному документі, який складається в письмовій формі відповідно до норм кримінального процесуального закону України і вручається особі, яка підозрюється у вчиненні кримінального правопорушення, що зумовлює набуття цією особою процесуального статусу підозрюваного, а також створює передумови для подальшого руху кримінального провадження та виконання завдань кримінального судочинства. Реалізація прокурором функції обвинувачення у кримінальному процесі, серед іншого, полягає у формуванні сукупності доказів для повідомлення особі про підозру у вчиненні кримінального правопорушення.

\section{Література}

1. Карпов Н.С. Наслідки незаконного повідомлення про підозру у кримінальному провадженні. Науковий вісник Херсонського державного університету. Херсон, 2014. Вип. 5. Т. 3. С. 132-136.

2. Кримінальний процес : підручник. / Ю.М. Грошевий, В.Я. Тацій, В.П. Пшонка та ін. ; за заг. ред. В.Я. Тація, В.П. Пшонки. Харків : Право, 2013. $824 \mathrm{C}$.

3. Бутенко С.Ю. Підстави позбавлення особи свободи під час досудового слідства і суду у практиці Європейського суду з прав людини. Правничий часопис Донецького університету. 2011. № 2. С. 90-97.

4. Слюсарчук Х.Р. Стандарти доказування у кримінальному провадженні : дис. ... канд. юрид. наук : 12.00.09. Львівський нац. ун-т ім. І. Франка, Львів, 2017. 258 c.

5. Настільна книга професійного судді (кримінальне провадження). / Н.О. Марчук, В.В. Касько, Р.О. Куйбіда, М.І. Хавронюк та ін. ; за ред. Н.О. Марчук. Київ : «Арт-Дизайн», 2015. 248 с.

6. Фараон О.В. Процесуальна форма письмового повідомлення про підозру у кримінальному провадженні. Науковий вісник Харківського національного університету. 2014. Вип. 1. Т. 8. С. 204-207.

7. Капліна О.В. Підозра у кримінальному провадженні: поняття, ознаки, сутність. Юридичний часопис Національної академії внутрішніх справ. 2013. № 1. C. 238-242. URL: http://nbuv.gov.ua/j-pdf/ aymvs_2013_1_43.pdf.

8. Боруш А.О. Інститут підозри в кримінальному провадженні: поняття, ознаки та значення. Науковий вісник Херсонського державного університету. Херсон, 2014. Вип. 6-1. Т. 4. С. 29-33.

9. Гринюк В.О. Функція обвинувачення в кримінальному провадженні України: теорія і практика : монографія. Київ : Алерта, 2016. 357 с.

10. Крет Г.Р. Міжнародні стандарти доказування у кримінальному процесі України: теоретико-правові та практичні основи : дис. ... д-ра юрид. наук. 12.00.09. Одеса, 2020. 544 с.

11. Гринюк В.О. Окремі питання вдосконалення процесуального порядку повідомлення про підозру. Сучасні проблеми криміналістики : матеріали Міжнародної науково-практичної конференції, присвяченої 100-річчю з дня народження доктора юридичних наук, професора В.П. Колмакова (м. Одеса, 27-28 вересня 2013 р.). / упоряд. В.В. Тіщенко, О.П. Ващук. Одеса : Юридична література, 2013. С. 93-96.

12. Кримінальний процесуальний кодекс України : Закон України від 13.04.2012 р. № 4651-VI. URL: http://zakon5.rada.gov.ua/laws/show/4651-17. 

досудового слідства

13. Погорецький М.А., Міцкан О.А. Стандарт доказування «обґрунтована підозра» у практиці Європейського суду з прав людини: вплив на вітчизняну правозастосовну практику. Вісник кримінального судочинства. 2019. № 1. С. 37-49.

14. Гловюк І.В., Степаненко А.С. Стандарт доказування «обґрунтована підозра» у кримінальному провадженні. Правова позиція. 2018. № 1. C. 13-20.

15. Ухвала Дзержинського районного суду м. Харкова від 25.03.2019 р. у справі № 638/11760/18 (провадження № 1-кс/638/1391/19). URL: http:// reyestr.court.gov.ua/Review/80811132.

16. Ухвала Подільського районного суду м. Києва від 12.12.2019 р. у справі № 758/15271/19 (провадження № 1-кс/758/5662/19). URL: http:// reyestr.court. gov.ua/Review/87076554.
17. Гринюк В.О. Повідомлення про підозру як форма здійснення первинного обвинувачення у кримінальному провадженні. Форум права. № 1. 2017. С. 20-25.

18. Лукашевич В.3. Обоснованность обвинения и гарантии прав обвиняемого в стадии предварительного расследования. Ученые записки ЛГУ. Вип. 8. С. 190-200.

19. Ляхов Ю.А. Обвиняемый на предварительном следствии в советском уголовном процессе : автореф. дисс. ... канд. юрид. наук. Ростов-на-Дону. 1956. 19 c.

Сухачова I. О., кандидат юридичних наук, докторант Національної академії внутрішніх справ 